Terakreditasi Sinta 3 | Volume 3 | Nomor 4 (Special Issue) | Tahun 2020 | Halaman 351-364

P-ISSN 2615-725X | E-ISSN 2615-8655

http://diglosiaunmul.com/index.php/diglosia/article/view/125

\title{
ANALISIS KELAYAKAN BUKU AJAR MILENIAL BERBASIS AUGMENTED REALITY (AR) SEBAGAI MEDIA PEMBELAJARAN TEKS PROSEDUR DI MAGELANG
}

\section{Feasibility Analysis of Augmented Reality (AR) Millenial Teaching Book as a Procedure Text Learning Media in Magelang}

\author{
Theresia Pinaka Ratna Ning Hapsari ${ }^{1, *}$ dan Ayu Wulandari ${ }^{2}$ \\ ${ }^{1,2}$ Pendidikan Bahasa dan Sastra Indonesia, FKIP, Universitas Tidar \\ Jalan Kapten Suparman 39 Magelang \\ 1,* Pos-el korespondensi: theresiapinaka@untidar.ac.id \\ ${ }^{2}$ Pos-el: ayuwulandari@untidar.ac.id
}

\begin{abstract}
This research was motivated by a problem in learning Indonesian in grade VII SMP with the material of Procedure Text. To overcome this, a learning media was made using technology to facilitate the distance learning process or independent learning. This study aims to describe the validity or feasibility value of millennial textbooks based on Augmented Reality technology used in learning Indonesian at the Junior High School level (SMP) in Procedure Text material. The Millennial Textbook is named The Magic Book, which is how it works using AR technology by displaying images on the book as well as 3D animation on Android-based devices. This research is a research and development or Research and Development (RnD) using the theory of Borg \& Gall which contains 3 major steps, namely design, testing, evaluation. This article contains validation tests from media experts and material experts to test the feasibility value of developed textbooks and limited field trials for seventh grade students at the junior high school level in Magelang City. The result of this feasibility test is that the material expert gives an assessment score of 122 from a maximum score of 130 or equivalent to $93.8 \%$ eligibility in a valid or suitable category for use in learning. The media expert gave an assessment score of 84 out of a maximum score of 90 or equivalent to $93.3 \%$ in the valid or feasible category for use as a medium in the learning process. The results of the field trial stated that the Magic Book was categorized as valid and feasible to be applied in teaching procedural texts for seventh grade students of SMP in Magelang.
\end{abstract}

Keywords: augmented reality, learning materials, procedur text, validity test

Abstrak: Penelitian ini dilatarbelakangi adanya masalah dalam pembelajaran bahasa Indonesia kelas VII SMP materi Teks Prosedur. Untuk mengatasi hal tersebut dibuatlah sebuah media pembelajaran dengan memanfaatkan teknologi untuk mempermudah proses pembelajaran jarak jauh atau pembelajaran mandiri. Penelitian ini bertujuan untuk mendeskripsikan validitas atau nilai kelayakan dari buku ajar milenial berbasis teknologi Augmented Reality yang digunakan dalam pembelajaran Bahasa Indonesia tingkat Sekolah Menengah Pertama (SMP) materi Teks Prosedur. Buku Ajar Milenial tersebut diberi nama Buku Ajaib yang cara kerjanya menggunakan teknologi AR dengan menampilkan gambar pada buku sekaligus animasi 3D di gawai berbasis android. Penelitian ini merupakan penelitian pengembangan atau Research and Develeopment (R $n D)$ menggunakan teori Borg \& Gall yang memuat 3 langkah besar, yakni perancangan, pengujian, evaluasi. Artikel ini memuat uji validasi dari ahli media dan ahli materi untuk menguji nilai kelayakan dari buku ajar yang dikembangkan dan uji lapangan terbatas kepada siswa kelas VII tingkat SMP di Kota Magelang. Hasil dari uji kelayakan ini adalah ahli materi memberikan skor penilaian 122 dari skor maksimal 130 atau setara dengan kelayakan 93,8\% dalam katerori valid atau layak untuk digunakan dalam pembelajaran. Ahli media memberikan skor penilaian sebesar 84 dari skor maksimal 90 atau setara dengan 93,3\% dalam katgori valid atau layak untuk digunakan sebagai media dalam proses pembelajaran. Hasil uji coba lapangan menyatakan 
bahwa Buku Ajaib dikategorikan valid dan layak untuk diaplikasikan dalam pembelajaran teks prosedur siswa kelas VII SMP di Magelang.

Kata kunci: angmented reality, analisis kelayakan, buku ajar, teks prosedur

\section{A. PENDAHULUAN}

Pandemi Covid-19 di Indonesia berimbas pada seluruh aspek kehidupan termasud bidang pendidikan. Pemerintah melakukan upaya pencegahan untuk menekan angka terjangkitnya rakyat Indonesia dari virus corona. Kementerian Pendidikan dan Kebudayaan (Kemendikbud) menerbitkan Surat Edaran Nomor 15 Tahun 2020 tentang Pedoman Penyelenggaraan Belajar Dari Rumah Dalam Masa Darurat Penyebaran Covid-19. Dalam surat edaran ini disebutkan bahwa tujuan dari pelaksanaan Belajar Dari Rumah (BDR) adalah memastikan pemenuhan hak peserta didik untuk mendapatkan layanan pendidikan selama darurat Covid-19, melindungi warga satuan pendidikan dari dampak buruk Covid-19, mencegah penyebaran dan penularan Covid-19 di satuan pendidikan dan memastikan pemenuhan dukungan psikososial bagi pendidik, peserta didik, dan orang tua. Dengan diberlakukannya kebijakan ini tidak dipungkiri menuai masalah baru dalam dunia pendidikan, yakni pembiasaan melakukan proses pembelajaran yang baru. Banyak guru dan siswa yang masih kesusahan untuk melakukan pembelajaran jarak jauh, meskipun pemerintah telah mengupayakan pembelajaran melalui semua media, baik media cetak maupun media elektronik serta dukungan dana di bidang pendidikan.

Tantangan tersebut haruslah segera diatasi oleh segenap satuan pendidikan, salah satunya oleh Kepala Sekolah sebagai ujung tombak di level bawah suatu lembaga pendidikan. Guru sebagai pelaksana kebijakan harus mampu melakukan pengajaran jarak jauh yang harus menggunakan teknologi sekaligus harus memiliki perlengkapan untuk pembelajaran online. Suharwoto (2020) mengungkapkan di tengah pandemi Covid-19 ini, sistem pendidikan Indonesia harus siap melakukan lompatan untuk melakukan transformasi pembelajaran daring bagi semua siswa dan oleh semua guru. Indonesia memasuki era baru untuk membangun kreatifitas, mengasah skill siswa, dan peningkatan kualitas diri dengan perubahan sistem, cara pandang dan pola interaksi kita dengan teknologi. Untuk itulah perlu adanya perombakan teknik dan metode pengajaran untuk menyesuaikan diri dengan pengajaran berbasis teknologi, termasuk di dalamnya adalah pengajaran bahasa Indonesia.

Mata pelajaran bahasa Indonesia merupakan mata pelajaran wajib dari jenjang Sekolah Dasar (SD), Sekolah Menegah Pertama (SMP), Sekolah Menegah Atas (SMA), hingga perguruan tinggi (PT). Melalui pembelajaran bahasa Indonesia, tak lain bertujuan untuk membekali peserta didik tentang ketrampilan berbahasa Indonesia yang meliputi keterampilan menyimak, keterampilan berbicara, keterampilan membaca, dan keterampilan menulis secara baik dan benar. Tujuan pembelajaran Bahasa dan Sastra Indonesia, seperti yang tercantum dalam kurikulum 2004 (Tim Depdiknas, 2004, hlm. 6) secara umum sebaiknya meliputi (1) siswa menghargai dan membanggakan Bahasa Indonesia sebagai bahasa persatuan (nasional) dan bahasa negara, (2) siswa memahami Bahasa Indonesia dari segi bentuk, makna, dan fungsi, serta menggunakannya dengan tepat dan kreatif untuk bermacam-macam tujuan, keperluan, dan keadaan, (3) siswa memiliki kemampuan menggunakan Bahasa Indonesia untuk meningkatkan kemampuan intelektual, kematangan emosional, dan kematangan sosial, (4) siswa memiliki disiplin dalam berpikir dan 
berbahasa (berbicara dan menulis), (5) siswa mampu menikmati dan memanfaatkan karya sastra untuk mengembangkan kepribadian, memperluas wawasan kehidupan, serta meningkatkan pengetahuan dan kemampuan berbahasa, dan (6) siswa menghargai dan membanggakan sastra Indonesia sebagai khazanah budaya dan intelektual manusia Indonesia.

$$
\text { Dalam kurikulum 2013, }
$$

pembelajaran bahasa Indonesia merupakan sarana untuk mengembangkan kemampuan dan keterampilan menalar. Paradigma pembelajaran bahasa Indonesia dalam Kurikulum 2013 diorientasikan pada pembelajaran berbasis teks. Pada pembelajaran berbasis teks ini, siswa dituntut agar mampu mengekspresikan dirinya melalui menulis. Sedangkan menurut Jayanti (2019) kegiatan pembelajaran bahasa Indonesia yang dianggap masih sulit adalah kegiatan menulis. Meskipun terasa sulit, siswa mau tidak mau harus mengahadapinya. Melalui kegaitan menulis, siswa diharapkan dapat menuangkan idenya, baik yang bersifat ilmiah maupun imajinatif. Namun, tanpa kreativitas mustahil bagi seseorang untuk bisa menghasilkan karya yang baik sebab menulis merupakan proses kreatif yang harus diasah secara terus menerus (Halijah, 2020). Oleh karena itu, Rosita (2018) menjelaskan sekolah tempat siswa menyenyam pendidikan diharapkan dapat memberikan pembelajaran menulis dengan baik dan menggunakan teknik yang tepat sehingga potensi dan daya kreativitas siswa dapat tersalurkan dengan baik.

Menurut Agustina

pembelajaran berbasis teks dirumuskan sebagai formula efektif untuk menyejajarkan pelaksanaan pendekatan ilmiah (pendekatan saintifik) sebagai teman sejati dalam pelaksanaan Kurikulum 2013. Teks yang diformulasikan ke dalam pembelajaran Bahasa Indonesia sebagai implementasi dari sistem budaya, sistem sosial, sistem kepribadian, dan sistem tingkah laku yang berlaku di masyarakat. Hadirnya konteks budaya (nilai, norma) dalam teks dapat ditunjukkan, misalnya pada teks laporan hasil observasi, teks deskripsi dan teks prosedur. Teks Prosedur merupakan salah satu materi teks yang diajarkan di kelas VII SMP. Menurut Kemendikbud (2016, hlm. 88) teks prosedur menjelaskan kegiatan yang harus dilakukan agar pembaca / pemirsa dapat secara tepat dan akurat mengikuti sebuah proses membuat sesuatu, melakukan suatu pekerjaan, atau menggunakan suatu alat. Melalui pembelajaran siswa dapat mengidentifikasi teks prosedur baik dari struktur teks, maupun ciri kebahasaannya.

Keterampilan menulis haruslah menghasilkan sebuah produk berupa tulisan, oleh karena itu keterampilan menulis seringkali dianggap sebagai keterampilan berbahasa yang paling sulit diantara keterampilan berbahasa lainnya (Halijah, 2020). Dalam penelitian ini, teks prosedur dipilih karena teks ini masih dirasa sulit untuk diproduksi oleh peserta didik di Kota Magelang. Mereka mengalami kesulitan dalam memahami materi kebahasaan dalam bentuk teks dan tingkat kreativitas memunculkan ide dan menuangkan ide dalam bentuk tulisan masih rendah. Hapsari (2020) dalam penelitiannya berjudul Analysis of the Need of Augmented Reality (AR) based Learning Media for The Prosedure Text Material menyebutkan bahwa siswa (1) mengalami kesulitan dalam memahami materi kebahasaan dalam bentuk teks; (2) tingkat kreativitas memunculkan ide dan menuangkan ide dalam bentuk tulisan masih rendah; dan (3) media pembelajaran yang digunakan masih konvensional. Untuk mengatasi permasalahan tersebut, dibutuhkan bahan ajar yang menarik, mengandung unsur gerak, dan menyenangkan. Peneliti mengembangkan bahan ajar yang diberi nama "Buku Ajaib" berbasis Augmented Reality (AR) yang sesuai 
untuk memvisualisasikan materi secara nyata dan menyenangkan.

Keberadaan bahan ajar sangat membantu dalam kegiatan belajar mengajar, agar materi lebih tersampaikan dengan baik kepada siswa. Keberadaan bahan ajar membuat siswa lebih tertarik untuk mempelajari materi yang diajarkan oleh guru (Nugroho, 2019). Bahan ajar merupakan sebuah materi yang disediakan dalam kegiatan pembelajaran yang mencakup buku teks, video, dan audiotapes, software computer, dan alat bantu visual.

Media pembelajaran termasuk dalam bahan ajar. Media pembelajaran merupakan suatu sarana komunikasi pembawa pesan dari sumber pesan kepada penerima pesan untuk menunjang proses pembelajaran.

Hartono

(2020) menjelaskan media pembelajaran membuat pengajaran akan lebih menarik perhatian siswa. Materi pelajaran akan lebih jelas maknanya, sehingga akan lebih mudah dipahami siswa. Media pembelajaran juga membuat metodoe mendidik akan lebih bervariasi, tidak semata-mata komuikasi verbal melalui penuturan kata-kata oleh guru sehingga siswa tidak bosan dan guru tidak kehabisan tenaga.

Senada dengan hal tersebut pengemasan bahan ajar yang diberi nama Buku Ajaib menggabungkan beberapa hal yang telah disebutkan di atas, yakni adanya materi yang dikemas dalam sebuah buku, terdapat contoh dari konsep yang sudah dijelaskan dalam bentuk video animasi yang bisa diakses melalui gawai berbasis android, sehingga pembuatan bahan ajar ini sangat kompleks dengan memanfaatkan teknologi yang berkembang dan sangat dekat dengan siswa.

Berkaitan dengan adanya permasalahan guru yang kurang kreatif dan inovatif dalam mengembangkan bahan ajar sehingga menyebabkan siswa kesulitan memproduksi teks prosedur, peneliti telah mengembangkan sebuah media pembelajaran "Buku Ajaib" berbasis Augmented Reality (AR) dengan objek 3D, teks, gambar, video, audio dapat menampilkan isi materi secara nyata. Hanya saja permasalahan yang diangkat dalam artikel ini secara khusus yaitu bagaimanakah nilai kelayakan dari media Buku Ajaib yang telah dikembangkan. Selaras dengan hal tersebut, tujuan dari penelitian ini adalah mendeskripsikan nilai kelayakan atau validitas dari bahan ajar yang dikembangkan, yakni Buku Ajaib dalam materi Teks Prosedur untuk siswa kelas VII SMP. Jika buku ajar dianggap layak digunakan dalam proses pembelajaran, selanjutnya akan dilakukan penelitian mengenai efektivitas penggunaan buku ajar terhadap kemampuan siswa dalam produksi teks prosedur atau tahap evaluasi dari pengembangan Buku Ajaib.

Tentunya Buku Ajaib berbasis Augmented Reality (AR) ini diciptakan untuk menjawab tantangan zaman yang masif kemajuannya. Saat ini adalah era milenial yakni berada di abad 21 era revolusi industri 4.0, berarti bahwa segala sesuatu dalam kehidupannya menggunakan kecanggihan teknologi.

Pengembangan media pembelajaran berbasis teknologi Augmented Reality mulai marak digunakan di era tahun 2000-an, namun penelitian pengembangan ini belum begitu banyak dilakukan di bidang pendidikan. Beberapa penelitian yang sudah dipublikasikan diantaranya milik Wahyudi (2017) dkk, yang telah menghasilkan produk media edukatif berbasis augmented reality untuk pembelajaran desain interior dan eksterior siswa SMK. Tujuan penelitiannya mendeskripsikan karakteristik media AR yang mampu meningkatkan kemampuan abstraksi siswa, dan mengevaluasi kelayakan (valid dan praktis) kemudian menguji keefektifan media AR. Metode yang digunakan adalah penelitian dan pengembangan model Borg \& Gall. Hasil 
penelitian menunjukkan bahwa media berbasis AR mampu meningkatkan daya abstraksi siswa dalam memahami pembelajaran desain interior dan eksterior. Media berbasis AR juga layak digunakan dalam pembelajaran. Berdasarkan beberapa tahapan uji coba, media berbasis AR dikategorikan valid, praktis, dan efektif digunakan dalam pembelajaran.

Penelitian selanjutnya milik Hakim (2018) bertujuan mendeskripsikan penggunaan teknologi AR dalam model pembelajaran PAI, diharapkan dapat membantu guru dalam proses pembelajaran dan juga mampu meningkatkan minat peserta didik dalam mengikuti proses pembelajaran. Metode penelitian yang digunakan adalah metode penelitian dan pengembangan (Research and Development) yang dirancang oleh $W$ alter Dick dan Lou Carey. Hasil dari penelitian adalah sebuah aplikasi Augmented Reality yang dapat berjalan di dalam smartphone android.

Melalui inspirasi tersebut dibawalah teknologi AR dalam sektor pendidikan khususnya pelajaran bahasa Indonesia materi Teks Prosedur karena dirasa penemuan ini belum pernah ada sebelumnya, sehingga penelitian ini adalah penelitian terobosan dalam menemukan media ajar yang baru, kreatif, dan inovatif, untuk digunakan siswa di masa pembelajaran mandiri.

Dengan adanya media pembelajaran ini diharapkan dapat mempermudah siswa dalam memahami materi secara menyenangkan. Apalagi di saat Pandemi Covid-19 ini diberlakukannya pembelajaran jarak jauh (pembelajaran daring) yang menuntut siswa untuk belajar secara mandiri. Sekolah memberlakukan kurikulum darurat (pada kondisi khusus) dengan tidak mengganti Kurikulum, SK, dan KD yang berlaku, hanya saja melakukan perampingan.

Dari pemaparan tersebut dapat disimpulkan bahwa siswa harus mampu mengikuti segala materi yang diberikan, namun pendampingan oleh guru dilakukan sangat minim. Maka dari itu dibutuhkan media pembelajaran yang kreatif dan inovatif untuk mendukung pemahaman siswa terhadap materi pelajaran dan membantu siswa untuk tetap produktif dalam menghasilkan tulisan, sesuai dengan $\mathrm{KD}$ yang telah ditetapkan sebelumnya. Harapannya, penggunaan media pembelajaran dengan Buku Ajaib dinilai efektif dan mampu mendukung produktivitas siswa menulis teks prosedur dalam pembelajaran bahasa Indonesia.

\section{B. METODE}

Penelitian ini merupakan jenis penelitian model pengembangan atau Research and Development (R\&D) aliran Borg \& Gall (1989) yang menggunakan 10 langkah yang harus ditempuh, yaitu: (1) penelitian dan pengumpulan informasi, (2) perencanaan, (3) pengembangan bentuk produk, (4) validasi produk, (5) revisi terhadap produk utama, (6) uji coba utama yang didasarkan pada hasil uji coba pendahuluan, (7) revisi produk operasional, (8) uji coba lapangan, (9) revisi produk akhir, dan (10) diseminasi dan implementasi. Akan tetapi, dalam artikel ini hanya sampai pada tahap ke 9 yakni revisi produk akhir. Evaluasi akan dilakukan pada penelitian yang berbeda setelah penelitian ini dikembangkan.

Sumber data dalam penelitian ini adalah guru dan siswa yang berlokasi di SMP Negeri 11 Magelang dengan subjek penelitian adalah siswa kelas VII. Data berupa jawaban dari angket yang diberikan oleh validator ahli materi dan validaror ahli media serta jawaban angket ujicoba yang diberikan oleh siswa kelas VII SMP Negeri 11 Magelang. Teknik pengumpulan data yang digunakan dalam penelitian ini menggunakan teknik angket. Instrumen yang digunakan adalah lembar validasi ahli materi dan ahli media serta angket respon siswa terhadap ujicoba pengembangan produk Buku Ajaib. Teknik analisis data yang dilakukan, yakni analisis deskriptif. 
Data yang dianalisis meliputi data kelayakan bahan ajar dari ahli materi dan ahli media serta respon siswa sebagai subjek uji coba.

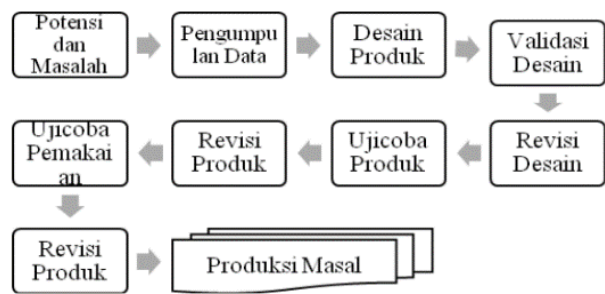

Gambar 1. Model Penelitian dan Pengembangan Aliran Borg \& Gall (1989)

\section{PEMBAHASAN}

Penelitian dan pengembangan bukanlah penelitian yang baru saja ditemukan dalam kegiatan pembelajaran, justru model penelitian dan pengembangan sudah ramai dilakukan di sektor pendidikan untuk meningkatkan kualitas pembelajaran pada umumnya. Penelitian dan pengembangan bisa dilakukan di berbagai sektor pembelajaran mulai dari pengembangan strategi pembelajaran, teknik pembelajaran, metode pembelajaran, hingga pengembangan bahan ajar yang meliputi materi, buku teks, hingga media pembelajaran. Produk yang dikembangkan pada penelitian ini adalah bahan ajar bahasa Indonesia materi "Teks Prosedur" bagi siswa SMP Kelas VII di Kota Magelang dengan memanfaatkan teknologi untuk menjawab tantangan pembelajaran mandiri atau pembelajaran jarak jauh pada masa darurat Covid-19..

Produk yang dihasilkan berupa sebuah buku yang memuat materi Teks Prosedur yang dikemas tidak hanya berupa teks saja melainkan juga menggunakan ilustrasi bergambar yang memudahkan siswa untuk belajar secara mandiri. Harapannya setelah membaca buku ini siswa bisa memiliki kemampuan menangkap materi secara lebih mudah dan dicerna dengan cepat hingga memunculkan ide untuk mengerjakan evaluasi dalam setiap kompetensi yang dituju, seperti menghasilkan teks prosedur secara mandiri. Selain bentuk buku berilustrasi gambar dan teks, disajikan pula materi dalam bentuk video. Siswa dapat mengaksesnya menggunakan gawai masing-masing dengan terlebih dahulu mengunduh aplikasi berupa software yang dapat ditemukan di market place sistem berbasis android.

Dalam buku tersebut terdapat sebuah barcode sistem yang berfungsi sebagai pintu masuk dari video yang akan diakses siswa. Siswa cukup memindai kode gambar yang terdapat dalam Buku Ajaib melalui aplikasi yang telah diunduh di gawai masing-masing. Kemudian siswa akan dibawa ke dalam sebuah ruang virtual yang membuat gambar di buku tersebut bergerak di gawainya. Teknologi inilah yang disebut dengan Augmented Reality (AR) atau realitas tertambah. AR merupakan teknologi gabungan antara benda maya dua atau tiga dimensi ke dalam sebuah lingkungan nyata lalu memproyeksikan benda-benda maya ke dalam waktu nyata. Benda maya tersebut berfungsi menampilkan informasi yang tidak dapat diterima oleh manusia secara langsung. Hal ini membuat realitas tertambah berguna sebagai alat untuk membantu persepsi dan interaksi penggunanya dengan dunia nyata. Informasi yang ditampilkan oleh benda maya membantu pengguna melaksanakan kegiatan-kegiatan dalam dunia nyata.

Menurut definisi Azuma (1997), ada tiga prinsip dari Augmented Reality, yaitu: (1) AR merupakan penggabungan dunia nyata dan virtual, (2) berjalan secara interaktif dalam waktu nyata (realtime), dan terdapat integrasi antarbenda dalam tiga dimensi, yaitu benda maya terintegrasi dalam dunia nyata. Secara sederhana AR bisa didefinisikan sebagai lingkungan nyata yang ditambahkan objek virtual. Penggabungan objek nyata dan virtual dimungkinkan dengan teknologi display yang sesuai, interaktivitas dimungkinkan 
melalui perangkat-perangkat input tertentu. AR memungkinkan pengguna untuk melihat lingkungan nyata, dengan objek yang ditambahkan atau tergabung dengan lingkungan nyata. Menurut Shapiro (2001) pembuatan sistem AR membutuhkan: (1) Model 3D dari objek untuk digabungkan dengan dunia nyata, (2) Korespondensi antara dunia nyata dengan model 3D melalui kalibrasi, (3) Tracking digunakan menentukan sudut pandangan pengguna terhadap dunia nyata, (4) Real-Time Display yang digabungkan dengan citra asli dan juga grafik komputer yang dibuat berdasarkan model, (5) Waktu respon terhadap gerakan dan akurasi antara gambar dan grafik sangat mempengaruhi keefektifan sistem.

Dalam perkembangannya $A R$ bukanlah teknologi yang baru, teknologi ini sudah sering kita jumpai dalam kehidupan sehari-hari hanya saja kita tidak menyadari bahwa teknologi itu dinamakan AR. Misalnya di media sosial seperti instagram, facebook, atau tiktok, adanya sebuah fungsi filter yang memindai wajah penggunanya kemudian filter tersebut menampilkan gambar-gambar yang mempercantik atau memperindah tampilan penggunanya. Padahal dalam dunia nyata pengguna tersebut tidak memakai apapun, hanya hasil akhir dari filter itu bisa memunculkan benda-benda yang sudah deprogram sebelumnya, seperti hiasan wajah, riasan/make up, hiasan kepala, dll.

\section{Proses Pengembangan Buku Ajar Berbasis Augmented Reality (AR)}

Pengembangan buku ajar teks prosedur berbasis Augmented Reality (AR) memiliki beberapa langkah untuk menunjang kelancaran pelaksanaan pengembangannya, yaitu (1) analisis kebutuhan dan karakteristik siswa, (2)merumuskan tujuan instruksional, (3) merumuskan butir-butir materi, (4) menulis naskah media, (5) perancangan media dan pembuatan media (6) validasi, (7) uji coba dan revisi. Kemudian untuk mendapatkan informasi mengenai kebutuhan dan karakteristik siswa, digunakan teknik wawancara dan teknik angket melalui google from. Hasil wawancara menunjukkan bahwa hasil pembelajaran materi teks prosedur belum cukup memuaskan, dilihat dari adanya beberapa siswa yang masih kesulitan dalam memproduksi teks prosedur dan memahami kaidah kebahasaannya sehingga mengakibatkan tidak terpenuhinya nilai standar ketuntasan minimal. Di sisi lain, pembelajaran bahasa Indonesia jarang menggunakan media pembelajaran yang inovatif. Hasil analisis angket kebutuhan dan karakteristik siswa SMP kelas VII sekota Magelang menunjukkan hasil sebagai berikut:
(a) $7,74 \%$ guru lebih sering menggunakan buku paket/LKS untuk mengajar teks prosedur;

(b) $87,2 \%$ siswa menginginkan buku pelajaran tidak hanya berisi tulisan, namun juga berisi ilustrasi 3 dimensi;

(c) $90,8 \%$ siswa lebih tertarik untuk belajar menggunakan media dengan memanfaatkan teknologi;

(d) $93 \%$ siswa menginginkan media pembelajaran yang bisa membantu memunculkan ide dalam membuat teks prosedur; dan

(e) $92 \%$ siswa lebih bersemangat belajar bila menggunakan media audio visual tidak hanya buku berisi tulisan.

Berdasarkan identifikasi tersebut, menunjukkan bahwa siswa kurang terfasilitasi dengan media pembelajaran yang menarik yang mampu membantu siswa dalam memproduksi teks prosedur, sehingga siswa membutuhkan adanya inovasi baru dalam pembelajaran teks prosedur. Setelah mengidentifikasi kebutuhan siswa, langkah selanjutnya adalah merumuskan tujuan, tujuan pembelajarannya adalah sebagai berikut: (1) setelah disajikan materi teks prosedur, 
siswa dapat mengidentifikasi ciri-ciri teks prosedur, (2) siswa mampu menyimpulkan teks prosedur yang sesuai struktur dan kaidah kebahasaan teks prosedur, (3) siswa dapat menelaah struktur dan aspek kebahasaan teks prosedur, (4) siswa dapat menggali kearifan lokal budaya di lingkungan sekitarnya dan mampu memproduksi teks prosedur dengan mengangkat kearifan budaya lokal di sekitarnya.

Langkah selanjutnya setelah merumuskan tujuan pembelajaran adalah menyusun materi. Materi yang digunakan adalah pengertian teks prosedur, tujuan teks prosedur, ciri-ciri teks prosedur dilihat dari segi isi dan kebahasaannya, jenis teks prosedur, struktur teks prosedur, dan contoh teks prosedur. Setelah itu, langkah selanjutnya yakni perancangan dan pembuatan media. Dalam tahapan ini peneliti merancang buku ajar sesuai dengan SK, KD, dan indikator pada Kurikulum 2013. KD yang dipilih yakni KD 3.5 Mengidentifikasi teks prosedur tentang cara melakukan sesuatu dan cara membuat (cara memainkan alat musik/tarian daerah, cara membuat kuliner khas daerah, dll) dari berbagai sumber yang dibaca dan didengar, dan $\mathrm{KD}$ 4.5 Menyimpulkan isi teks prosedur tentang cara melakukan sesuatu dan cara membuat (cara memainkan alat music/tarian daerah, cara membuat kuliner khas daerah, dll) dari berbagai sumber yang dibaca dan didengar.

Tahapan pertama yang dilakukan dalam tahap perancangan adalah pembuatan "Buku Ajaib". Bahan Ajar yang dikembangkan ini berisikan materi teks prosedur, contoh, dan evaluasi kinerja, yang mirip seperti modul pembelajaran. Dalam buku ini dibuat gambar yang menarik dan penuh warna dengan minim kata yang memuat contoh teks prosedur berupa langkah-langkah membuat wayang kardus. Contoh yang diangkat mengenai pembuatan wayang kardus dipilih berdasarkan data yang telah dilakukan sebelumnya. Kota Magelang memiliki seniman pembuat wayang yang berbeda dari yang lain, karena ia membuat wayang bukan dari kulit hewan seperti wayang pada umumnya, melainkan dari bahan bekas pakai yakni kardus bekas. Hal ini dipilih karena pembuatan wayang menggunakan kardus tergolong murah dan pembuatannya juga mudah, menggunakan bahan-bahan yang ada di sekitar lingkungan.

Wayang merupakan warisan budaya Indonesia yang harus dilestarikan, dan harus dipopulerkan di kalangan anak muda. Siswa SMP Kelas VII wajib diberi muatan lokal untuk menumbuhkan kecintaannya terhadap budaya bangsanya sendiri supaya tidak hilang dimakan zaman. Wayang yang dianggap sesuatu yang kuno dan susah kini bisa dihadirkan dalam kemasan yang baru sehingga bisa diterima oleh kalangan milenial. Contoh ini merupakan hal yang sederhana yang dihadirkan supaya membentuk pemikiran siswa bahwa membuat teks prosedur tidaklah susah, karena menulis berdasarkan apa yang ada di sekitar lingkungan, tidak perlu jauh-jauh atau hal yang rumit untuk dijadikan inspirasi dalam pembuatan teks prosedur. Budaya Jawa atau Indonesia sangat beragam sehingga tidak akan mungkin kehabisan ide untuk memunculkan inspirasi dalam memproduksi teks prosedur secara mandiri.

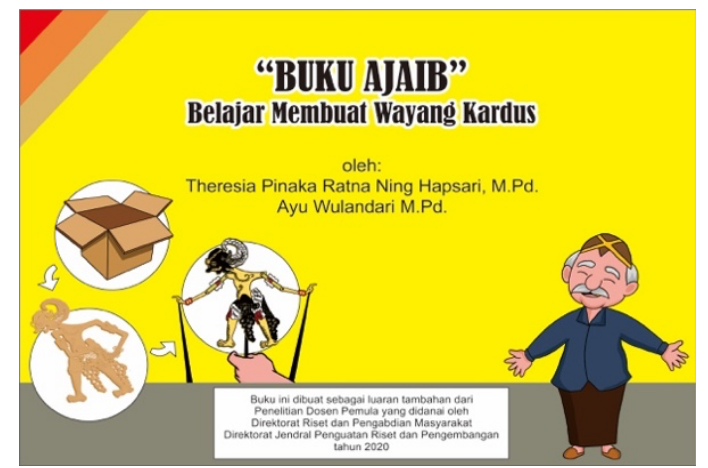

Gambar 2. Cover Buku Ajaib yang dikembangkan dengan Teknologi AR 
Setelah melakukan perancangan produk, langkah selanjutnya yaitu pengembangan bentuk produk. Setelah peneliti membuat buku ajar dalam bentuk gambar, peneliti mengembangkannya dalam bentuk video 3 dimensi. Setelahnya gambar dan video tersebut digabungkan menggunakan teknik Augmented Reality $(A R)$. beberapa gambar diberi kode supaya dapat dipindai dalam bentuk video. Kemudian setelah pembuatan alat pemindai gambar untuk dijadikan video, barulah peneliti membuat software atau aplikasi yang bisa digunakan dalam gawai berbasis android, supaya siswa bisa mengakses aplikasi tersebut secara mudah dan cepat. Setelah media pembelajaran selesai diproduksi, langkah selanjutnya adalah dengan mengujinya pada validator ahli pada tahap implementasi uji coba.

\section{Kelayakan Media Buku Ajaib Berbasis Augmented Reality (AR)}

Pada subbab ini akan dijabarkan analisi kelayakan media "Buku Ajaib" berbasis Augmented Reality (AR) dalam pembelajaran menulis teks prosedur dilihat dari penilaian validator ahli. Validasi yang dilakukan yakni validasi dari ahli materi dan ahli media. Kemudian validasi media dari siswa untuk mengetahui kelayakan dan ketepatan akan kebutuhan siswa terpenuhi untuk membantu siswa dalam belajar memahami dan memproduksi teks prosedur.

Seperti yang telah dijabarkan sebelumnya, fokus penelitian ini adalah mencari nilai kelayakan dari bahan ajar yang telah dikembangkan. Untuk itu pembahasan yang dilakukan hanya terfokus pada analisis kelayakannya saja. Hasil akhir dan evaluasi akan dilaksanakan pada penelitian selanjutnya. Data penilaian yang diberikan para ahli dalam menilai kelayakan dari bahan ajar Buku Ajaib dapat dilihat pada Tabel 1.

\section{a. Validasi Ahli Materi}

Ahli materi yang dipilih adalah seorang dosen dari Universitas Sebelas Maret bernama Aloysius Indratmo, M.Hum. Lembar validasi ahli materi dibuat terdiri dari 26 kriteria penilaian dengan masing-masing kriteria diminta memberi skor $1-5$ skala Likert. Skor 1 hingga 5 secara berurutan menunjukkan tingkatan penilaian mulai dari nilai sangat rendah, rendah, cukup, tinggi, dan sangat tinggi.

Tabel 1. Data Penilaian Bahan Ajar dari Validator

\begin{tabular}{clccc}
\hline No & Aspek Penilaian & Skor Perolehan & Skor Maksimal & Persentase \\
\hline 1 & Ahli Materi & 122 & 130 & $93,8 \%$ \\
2 & Ahli Media & 84 & 90 & $93,3 \%$ \\
3 & Uji coba siswa & 63,9 & 75 & $85,1 \%$ \\
\hline
\end{tabular}

Tabel 2. Kriteria Hasil Evaluasi Kelayakan Ahli

\begin{tabular}{ll}
\hline Persentase & Keterangan \\
\hline $80 \%-100 \%$ & Valid / digunakan \\
$60 \%-79 \%$ & Cukup Valid / digunakan \\
$50 \%-59 \%$ & Kurang Valid / diganti \\
$<50 \%$ & Tidak Valid / diganti \\
\hline
\end{tabular}

Sumber: Sudjana (2005, hlm. 45) 
Kriteria penilaian yang ditentukan secara garis besar meliputi: (1) ketepatan isi materi berupa pengertian, tujuan, ciriciri, jenis, struktur, ciri kebahasaan, contoh teks prosedur dengan kompetisi yang ingin dicapai, (2) kelengkapan isi materi berupa pengertian, tujuan, ciri-ciri, jenis, struktur, ciri kebahasaan, contoh teks prosedur dengan kompetisi yang ingin dicapai, (3) keruntutan materi, (4) penyajian materi dapat memberi bantuan untuk belajar, memberi tambahan pengetahuan, menarik minat belajar, menumbuhkan rasa ingin tahu, meningkatkan minat baca, meningkatkan keaktifan, dan contoh berupa konten lokal, dan (5) penggunaan bahasa yang jelas, sesuai ejaan, dan mudah dipahami. Dari kriteria yang telah ditentukan tersebut, validator memberi skor 122 dari skor maksimal 130. Hal ini menunjukkan bahwa materi yang dimuat dalam buku ajar valid sesuai dengan SK, KD, Kurikulum 2013.

Hasil validasi ahli materi, kelayakan aspek materi "Buku Ajaib" bahan ajar yang dapat digunakan sebagai media pembelajaran berbasis Augmented Reality (AR) untuk materi pelajaran bahasa Indonesia teks prosedur kelas VII SMP, terdapat sejumlah 26 butir soal yang memuat kriteria penilaian kelayakan. Terdapat 18 butir soal kriteria penilaian yang diberi skor 5 (sangat tinggi) oleh validator dan 8 butir soal kroteria penulaian yang diberi skor 4 (tinggi), sehingga total skor yang didapatkan adalah $(18 \times 5=90)+(8 \times 4=32)=122$. Untuk mendapatkan persentase hasil kelayakan didapat dengan rumus: skor perolehan dibagi skor maksimal dikalikan 100\% untuk itu didapatkan hasil persentase kelayakan dari validator ahli materi sebesar 93,8\%

Berdasarkan Tabel 2, terkait persentase hasil evaluasi kelayakan yang diberikan oleh ahli materi, maka sajian materi yang termuat di dalam Buku Ajaib sebesar 93,8\% tergolong valid atau dapat digunakan.

\section{b. Validasi Ahli Media}

Ahli media yang dipilih adalah seorang produser TV yang bekerja di salah satu TV milik pemerintah daerah Temanggung, bernama Tegar Aldrian Rosdianto, S.I.Kom. Kriteria penilaian yang ditentukan terdiri dari 18 butir soal yang meliputi: (1) kesesuaian gambar (dari buku) dan video (dari animasi AR) yang ditampilkan dengan materi yang disampaikan, (2) kesesuaian ukuran gambar/video, (3) kejelasan gambar/video dan suara/musik, (4) kemudahan pengoperasian, (5) kesesuaian warna, bentuk dan ukuran huruf, serta teks yang terbaca, (6) ketepatan penggunaan bahasa lisan, kejelasan pengisi suara, (7) kualitas animasi, dan (8) keserasian.

Dari 18 butir soal kriteria penilaian, validator memberi skor 84 dari skor maksimal 90 poin. Hal ini menunjukkan bahwa dari segi pembuatan media, bahan ajar pembelajaran "Buku Ajaib" ini sudah bisa digunakan untuk pembelajaran teks prosedur. Terdapat catatan tambahan dari ahli media yang tergolong catatan positif dan dorongan semangat atau support yaitu media yang dibuat sudah bisa digunakan untuk meningkatkan literasi siswa dan peningkatan pemahaman terhadap langkah-langkah pembuatan sesuatu (benda). Kemudian saran atau masukan yang diberikan oleh ahli media adalah supaya bisa sesegera mungkin disebarkannya buku ajar tersebut untuk menunjang pembelajaran mandiri.

Hasil validasi ahli media, kelayakan aspek media "Buku Ajaib", sebagai bahan pembelajaran berbasis Augmented Reality (AR) untuk materi pelajaran bahasa Indonesia teks prosedur kelas VII SMP yang berjumlah 18 butir soal kriteria penilaian, terdapat 12 butir soal kriteria penilaian yang diberi nilai 5 (sangat tinggi) oleh validator dan 6 butir soal kriteria 
penilaian yang diberi nilai 4 (tinggi) oleh validator, sehingga total skor adalah $(12 \times 5=60)+(6 \times 4=24)=84$. Jika disesuaikan dengan nilai persentase, perolehan skor tersebut bernilai 93,3\%. melihat kembali Tabel 2 tentang persentase hasil evaluasi kelayakan yang diberikan oleh ahli media, maka penggunaan media yang digunakan dalam Buku Ajaib sekaligus video animasi 3D dalam aplikasi android dengan teknologi AR memiliki persentase nilai sebesar 93,3\% yang tergolong valid atau dapat digunakan.

\section{c. Validasi Siswa}

Validasi bahan ajar dengan media "Buku Ajaib" dilakukan oleh siswa kelas VII SMP Negeri 11 Kota Magelang. Tentunya validator dari siswa bukanlah merupakan seluruh siswa kelas VII, melainkan hanya sebagian saja yang dipilih atau hanya 1 kelas sampel sebagai validator yang memberi penilaian awal. Kelas ini juga bukanlah kelas ujicoba karena kelas ujicoba merupakan kelas yang belum dipilih dengan alasan tahap evaluasi belum dilakukan. Penilaian ini termasuk dalam penilaian terbatas yang berarti sebagian kecil siswa yang hanya dipilih sebagai validator awal uji coba media.

Kelas yang dipilih untuk memvalidasi bahan ajar berupa media "Buku Ajaib" dipilih secara random atau acak. Tidak ada kriteria khusus memperhatikan bahwa semua siswa pada setiap kelas di tingkat VII SMP Negeri 11 Kota Magelang ini kualitasnya sama rata, tidak ada kelas yang dikhususkan untuk siswa pintar, menengah, atau kelas rendah. Kompetensi siswa pada setiap kelas sama, matei yang diterima setiap kelas sama, dan pembelajaran yang dilakukan juga sama. Siswa yang dipilih untuk memvalidasi media "Buku Pintar" ini adalah siswa kelas VII A dengan jumlah siswa ada 36.

Terkait lembar hasil validasi siswa, terdapat 15 butir soal kriteria penilaian bahan ajar menggunakan media Buku
Ajaib. Kriteria tersebut terdiri dari beberapa garis besar penilaian yaitu: (1) segi penyajian, (2) segi kejelasan, (3) segi keterbacaan, (4) kemudahan. Penilaian masih menggunakan skala likert yaitu skor 1-5 yang diberikan oleh siswa memuat penilaian dari sangat rendah hingga sangat tinggi. dari lembar hasil validasi siswa memiliki skor yang beragam dari satu siswa ke siswa yang lainnya. Jika dirangkumkan dari total 15 butir soal keriteria penulaian uji validitas memiliki skor maksimal 75. Rata-rata penilaian yang diberikan oleh siswa berada di skor 63.9 dengan persentase nilai $85.1 \%$. Jika melihat kembali Tabel 1 tentang persentase hasil evaluasi kelayakan yang diberikan oleh validator yang kali ini adalah 36 siswa kelas VII SMP, maka bahan ajar dengan media Buku Ajaib untuk materi teks prosedur mata pelajaran bahasa Indonesia tergolong valid atau dapat digunakan.

Secara keseluruhan terlihat dengan jelas bahwa seluruh validator yang terdiri dari ahli materi, ahli media, dan uji coba terbatas pada siswa, kesemuanya memberi nilai yang persentasenya dikategorikan valid atau bahan ajar yang telah dikembangkan dapat digunakan. Langkah yang selanjutnya akan ditempuh yakni melakukan evaluasi dari pengembangan media yang telah dianalisis kelayakannya. Hal ini merupakan penelitian lanjutan yang akan dilakukan dan hasil penelitian akan terpisah dari artikel yang saat ini telah dibuat. Berdasarkan analisis kelayakan media yang telah dilakukan, maka disimpulkan bahwa bahan ajar berupa Buku Ajaib yang dikembangkan dengan teknologi Augmented Reality dikatakan layak untuk digunakan untuk pembelajaran teks prosedur mata pelajaran bahasa Indonesia kelas VII SMP di Kota Magelang.

\section{PENUTUP}

Berdasarkan hasil analisis dan pembahasan, dapat diambil simpulan secara keseluruhan, proses pengembangan 
bahan ajar yang diberi nama media "Buku Ajaib" berbasis teknologi Augmented Reality (AR) berlangsung baik dan lancar. Proses pengembangan media ini dilakukan dengan tahap-tahap pengembangan yaitu tahap pertama, mengidentifikasi kebutuhan dan karakteristik peserta didik dengan cara membagikan angket identifikasi kebutuhan siswa dan wawancara dengan guru bahasa Indonesia SMP Negeri sekota Magelang. Setelah mengetahui kebutuhan dan karakteristik peserta didik, dilakukanlah proses penyusunan bahan ajar menggunakan media "Buku Ajaib" berbasis Augmented Reality (AR) dengan menyusun naskah media terlebih dahulu, yang kemudian draf akan divalidasi oleh validator ahli, yakni validasi dari ahli materi dan ahli media.

Ahli materi yang dipilih adalah seorang dosen dari Universitas Sebelas Maret bernama Drs. Aloysius Indratmo, M,Hum. Dari kriteria yang telah ditentukan, validator memberi poin 122 dari total poin keseluruhan 130, hal ini menunjukkan materi yang dimuat dalam buku ajar valid dan dapat digunakan dalam proses pembelajaran sesuai dengan SK, KD, Kurikulum 2013. Ahli media yang dipilih adalah seorang produser TV yang bekerja di salah satu TV milik pemerintah daerah Temanggung, bernama Tegar Aldrian Rosdianto, S.I.Kom.

Validator ahli media memberi penilaian dengan skor 84 dari skor maksimal 90 poin. Hal tersebut menandakan bahwa media "Buku Ajaib" berbasis Augmented Reality (AR) layak untuk dijadikan media pembelajaran teks prosedur di sekolah. Kemudian validasi dari 36 siswa kelas VII A SMP Negeri 11 Kota Magelang rata-rata jawaban siswa berada di skor 63.9 dengan persentase nilai $85.19 \%$ maka kualitas media layak dengan kategori dapat digunakan untuk proses pembelajaran secara mandiri.

Bahan ajar yang dikembangkan juga mendukung adanya proses pembelajaran jarak jauh (PJJ) atau belajar secara mandiri yang dilakukan oleh siswa di Indonesia selama masa pandemi Covid-19. Adanya bahan ajar yang kreatif dan inovatif merupakan solusi dari permasalahan umum siswa yang merasa kesulitan untuk memproduksi teks. Dengan adanya Buku Ajaib diharapkan bisa memperbaiki kualitas pengajaran supaya tujuan pembelajaran dapat tercapai tanpa adanya hambatan, sehingga kompetensi dari hasil belajar siswa yang diharapkan juga dapat diraih. Selanjutnya pembuatan bahan ajar dengan memanfaatkan teknologi diharapkan tidak berhenti namun terus menerus bisa dikembangkan dan dihasilkan untuk mendukung terciptanya merdeka belajar.

\section{DAFTAR PUSTAKA}

Agustina, E. S. (2017). Pembelajaran Bahasa Indonesia Berbasis Teks: Representasi Kurikulum 2013. AKSARA: Jurnal Bahasa dan Sastra, 18(1), 84-99.

Amalia, A., \& Doyin, M. (2015). Pengembangan Buku Panduan Menyusun Teks Cerpen dengan Menggunakan Teknik Urai Unsur Intrinsik bagi Siswa Kelas VII Sekolah Menengah Pertama (SMP). Jurnal Pendidikan Bahasa dan Sastra Indonesia, 4(2), 1-6.

Amy, N. W., \& Pradipta, A. W. (2019). Kelayakan Aspek Materi, Bahasa dan Media pada Pengembangan Buku Ajar Statistika untuk Pendidikan Olahraga di IKIP Budi Utomo Malang. Efektor, 6(1).

Arsanti, M. (2018). Pengembangan Bahan Ajar Mata Kuliah Penulisan Kreatif Bermuatan Nilai-nilai Pendidikan Karakter Religius bagi Mahasiswa Prodi PBSI, FKIP, UNISSULA. KREDO: Jurnal Ilmiah Bahasa dan Sastra, 1(2).

Astrini, L. (2013). Pengembangan Bahan Ajar Menulis Petunjuk bagi Pembelajaran dengan Pendekatan Kontekstual pada 
Siswa SMP. Universitas Negeri Semarang.

Ayuningrum, F. (2012). Pengembangan Media Video Pembelajaran untuk Siswa Kelas X pada Kompetensi Mengolah SOUP Kontinental di SMK N 2 Godean. Universitas Negeri Yogyakarta.

Azuma, R. (1997). A survey of augmented reality. Presence: Teleoperators and Virtual Environments, 6(4), 355-385.

Borg, W.R., \& Gall, M. (1989). Education Research: An Introduction (4 ${ }^{\text {th }}$ Edition). New York: Longman Publisher.

Bradski, G., Kaehler, \& Adrian. (2008). Learning Open CV. Edisi 1. California: O’Reilly Media.

Damayanti, Eka, A., \& dkk. (2018). Kelayakan Media Pembelajaran Fisika Berupa Buku Saku Berbasis Android Pada Materi Fluida Statis. Unit Riset dan Publikasi Ilmiah FTK UIN Raden Intan Lampung.

Depdiknas. (2004). Kerangka Dasar Kurikulum 2004. Jakarta: Departemen Pendidikan Nasional.

Devi, P.C. (2018). Pengembangan Bahan Ajar Menulis Teks Prosedur Kompleks dengan Model Pembelajaran Discovery Learning Menggunakan Media Audio Visual (Video) di Kelas XI SMA Negeri 1 Samarinda. Diaglosia: Jumal Kajian Babasa, Sastra, dan Pengajarannya, 1(2), 101-114.

Fernando, M. (2013). Membuat Aplikasi Android AR Menggunakan Vuforia SDK dan Unity. Buku AR Online, Solo.

Hakim, L. (2018). Pengembangan Media Pembelajaran PAI Berbasis Augmented Reality. Jurnal Lentera Pendidikan, 20(1), 59-72.

Halijah, S., Susilo, \& Mulawarman, W. G. (2020). Pengembangan Bahan Ajar Menulis Deskripsi Menggunakan Model Kooperatif Round Table dengan Media Audio pada Siswa
Kelas X SMA. Diglosia, 3(2), 115124.

Hapsari, T. P. R. N, \& Wulandari, A. (2020). Analysis of the Need of Augmented Reality (AR) based Learning Media for The Prosedure Text Material. ICoISSE, 1(1), 118127

Hartono, R., Susilo, \& Hudiyono, Y. (2020). Penerapan Macromedia Flash dalam Meningkatkan Kreativitas, Hasil Belajar, dan Efektivitas Pembelajaran Siswa Kelas XII di SMK Negeri 1 Kaliorang. Diglosia: Jurnal Kajian Bahasa, Sastra, dan Pengajarannya, 3(2), 221-228.

Jayanti, R., \& Rosita, Y. D. (2019). Pengembangan Kompetensi Kebahasaan dalam Menulis Teks Cerpen Sejarah di MAN 7 Jombang. Kembara: Jurnal Keilmuan Bahasa, Sastra, dan Pengajarannya, 5(2), 245253.

Martin, B. L. \& Briggs, L.J., (1986). The Affective and Cognitive Domains: Integration for Instruction and Research. Englewood Cliffs, NJ: Educational.

Oemar, H. M. (1994). Media Pendidikan. Bandung: Citra Aditya.

Pramudito, A. (2013). Pengembangan Media Pembelajaran Video Tutorial pada Mata Pelajaran Kompetensi Kejuruan Standar Kompetensi Melakukan Pekerjaan dengan mesin Bubut di SMK Muhammadiyah 1 Playen. Universitas Negeri Yogyakarta.

Rosita, F. Y. (2018). Pengembangan Model Pembelajaran Timnas untik Menulis Puisi pada Siswa SMP Kelas VIII. Kembara: Jurnal Keilmuan Bahasa, Sastra, dan Pengajarannya, 4(1), 35-47.

Shapiro, Linda, \& Stockman, G. C. (2001). Computer Vision. Prentice-Hall. New Jersey, 279-325.

Sudjana, N. (2005). Media Pengajaran (Penggunaan dan Pembuatannya). Bandung: Percetakan Sinar Baru Algensindo Offset. 
Sudjana. (2005). Metode Statistika. Bandung: Tarsito.

Sugiyono, P. (2014). Metode Penelitian Kuantitatif dan Kualitatif dan R\&D. Bandung: Alfabeta.

Suharwoto, G. (2020). Pembelajaran Online di Tengah Pandemi Covid-19, Tantangan yang Mendewasakan. https://pusdatin.kemdikbud.go.id/ pembelajaran-online-di-tengahpandemi-covid-19-tantangan-yang- mendewasakan/ diakses pada tanggal 1 Oktober 2020 pk 19.58 WIB

Wahyudi, Wiji, U. P., Wibawanto, H., \& Hardyanto, W. (2017). Pengembangan Media Edukatif Berbasis Augmented Reality untuk Desain Interior dan Eksterior. Innovative Journal of Curriculum and Educational Technology (IJCET), 6(2), 98-107. 